\title{
Working
}

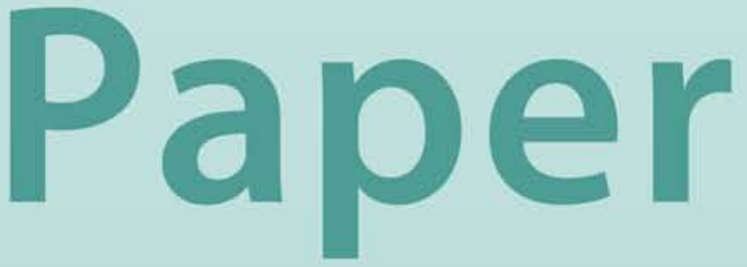


Zero Corporate Income Tax in Moldova: Tax Competition and Its Implications for Eastern Europe

Marcin Piatkowski and Mariusz Jarmuzek 


\title{
IMF Working Paper
}

\author{
European Department
}

\section{Zero Corporate Income Tax in Moldova: Tax Competition and Its Implications for Eastern Europe}

\author{
Prepared by Marcin Piatkowski and Mariusz Jarmuzek ${ }^{1}$
}

Authorized for distribution by Subhash Thakur

August 2008

\begin{abstract}
This Working Paper should not be reported as representing the views of the IMF. The views expressed in this Working Paper are those of the author(s) and do not necessarily represent those of the IMF or IMF policy. Working Papers describe research in progress by the author(s) and are published to elicit comments and to further debate.

Global economic integration intensified tax competition and raised concerns about the resulting "race to the bottom", which could undermine public investment and social spending. The aim of this paper is to test predictions that (i) there is interdependence in CIT rate setting in Eastern Europe and that (ii) the recent CIT cut in Moldova may intensify tax competition in the region. It finds that there is indeed evidence that during 1995-2006 countries in Eastern Europe strategically responded to changes in CIT rates in the region and that Moldovan zero CIT is likely to encourage further cuts in CIT. The paper also discusses implications of tax competition for Eastern Europe and finds that FDI flows will not be much affected, tax revenues are likely to decline, the shift in the composition in tax revenue may increase economic efficiency, but decrease equity. Tax coordination, while difficult politically, could help stem further decline in corporate taxation, but any gains might be modest and not certain to exceed the costs of tax coordination. Without tax coordination, however, it is unclear what exactly could stop corporate taxes from falling further.
\end{abstract}

JEL Classification Numbers: $\mathrm{H} 0 ; \mathrm{H} 25 ; \mathrm{H} 77$

Keywords: Tax competition; Corporate Taxes

Authors’ E-Mail Address: marcin.piatkowski@pkobp.pl and mjarmuzek@imf.org

\footnotetext{
${ }^{1}$ The paper was written while Marcin Piatkowski, currently chief economist of PKO BP, was with the European Department of the IMF. We would like to thank Engin Dalgic, Alexander Klemm, Tetsuya Konuki, Wojciech Maliszewski, Andrzej Raczko and the reviewers for valuable comments and suggestions. We are also grateful to Saida Mamedova for excellent research assistance.
} 
Contents

I. Introduction $\underline{3}$

II. Do Countries Compete Over Corporate Taxes? .........................................................

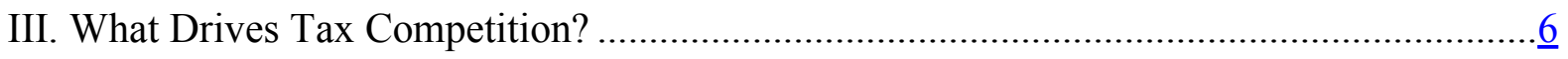

IV. Will the Moldovan Zero CIT Intensify Tax Competition in the Region? ........................ 7

V. Implications for FDI, Economic Efficiency, Equity, and Welfare ................................. $\underline{9}$

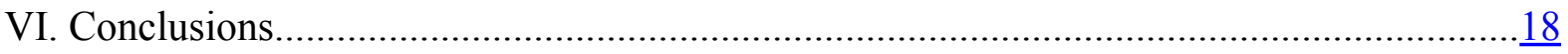

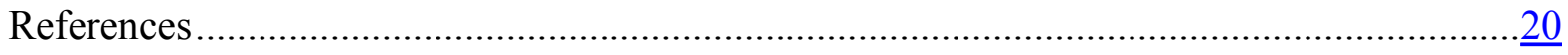

Table

1. Strategic Interaction in CIT Setting in Eastern Europe, 1995-2006 ................................ $\underline{8}$

Figures

1. CIT Rate in the EU-15 and Eastern Europe.............................................................. 4

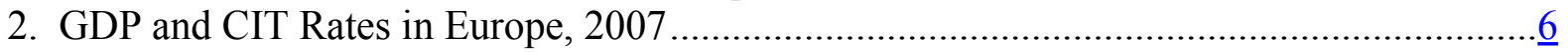

3. Ratio of US FDI to GDP for Four Groups of Countries ............................................ 10

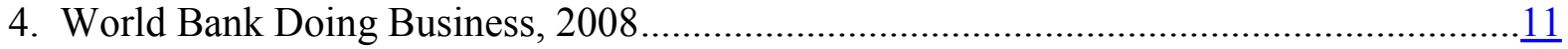

5. Eastern Europe: CIT Rate and Revenue .................................................................... 11

6. Statutory and Effective CIT Rates in NMS-8 …................................................... $\frac{12}{13}$

7. NMS-10: Gross Operating Surplus and Mixed Income.................................................13

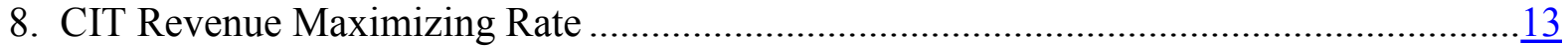

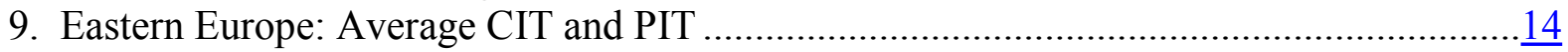

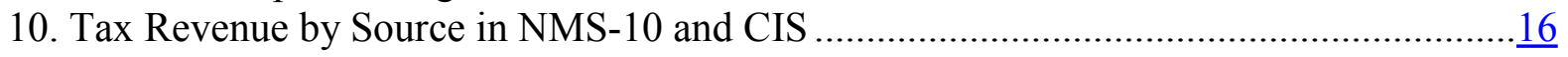

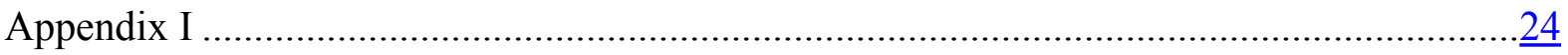




\section{INTRODUCTION}

Global economic integration and technological innovations have reduced barriers for flows of capital and labor and intensified tax competition over mobile capital. This led to significant declines in corporate income tax (CIT) rates in Western and Eastern Europe and raised concerns about tax competition and the resulting "race to the bottom." Policymakers, the public and some economists, particularly in Western Europe, have become concerned that reductions in CIT rates may lower tax revenue and force countries to increase other, more distortionary taxes, reduce public investment, and/or cut social spending. This could happen exactly at the time when globalization strengthens demands for social welfare programs and when countries struggle to deal with the growing pressures on pension and healthcare systems owing to ageing. They are also worried that some countries ignore the potentially harmful impact of their decisions on other countries leading to a "beggar-thy-neighbor" polices and driving corporate tax rates below welfare-optimal levels. Finally, an erosion of capital income taxation could undermine the integrity and political legitimacy of the tax system and lead to greater inequality. ${ }^{2}$

Moldova's decision to cut the CIT rate to zero in 2008 is likely to intensify concerns about tax competition, especially as it can encourage other countries in Eastern Europe to lower (the already low) corporate taxes further to attract FDI and mobile profits, improve domestic political standing, or provide a signal of business-friendly policies. ${ }^{3}$

The purpose of the paper is twofold: first, to test the prediction that (i) there is interdependence in CIT rate setting in Eastern Europe and (ii) that the Moldovan zero CIT will intensify tax competition in Eastern Europe, including ten new EU member states (NMS-10), European countries of the Commonwealth of the Independent States (CIS), and transition economies of Southeastern Europe (SEE); second, to discuss the implications of regional tax competition for the flows of foreign direct investment, tax revenues, economic efficiency, equity, and social welfare.

The paper is organized as follows. In sections B and C, the paper discusses if, why, and how countries compete over corporate tax rates. In section $\mathrm{D}$, the paper provides empirical evidence that countries in Eastern Europe strategically respond to changes in CIT rates in the region and that the Moldovan zero CIT is likely to intensify tax competition. Section E analyzes the implications of tax competition and discusses whether tax coordination would be beneficial. Section F concludes.

\footnotetext{
${ }^{2}$ See the literature surveys by Wilson (1999), Zodrow (2003), and Devereux and Loretz (2007).

${ }^{3}$ Unlike in Estonia, Moldova kept the standard system of corporate taxation, but reduced the rate to zero. It will continue to tax dividends and non-business expenses. The Moldovan authorities do not rule out raising the CIT rate in the future.
} 


\section{Do Countries Compete Over CoRporate TaXes?}

CIT rates have declined considerably in the last decade. In Western Europe, mean statutory CIT rates declined from 38 percent in 1995 to 28 percent in 2008; in new EU members states (NMS-10), they fell from 32 percent in 1995 to below 18 percent in 2008. Likewise, CIT rates also fell in CIS and SEE countries (Figure 1). ${ }^{4}$ The decline in CIT rates is likely to continue in the near future. ${ }^{5}$

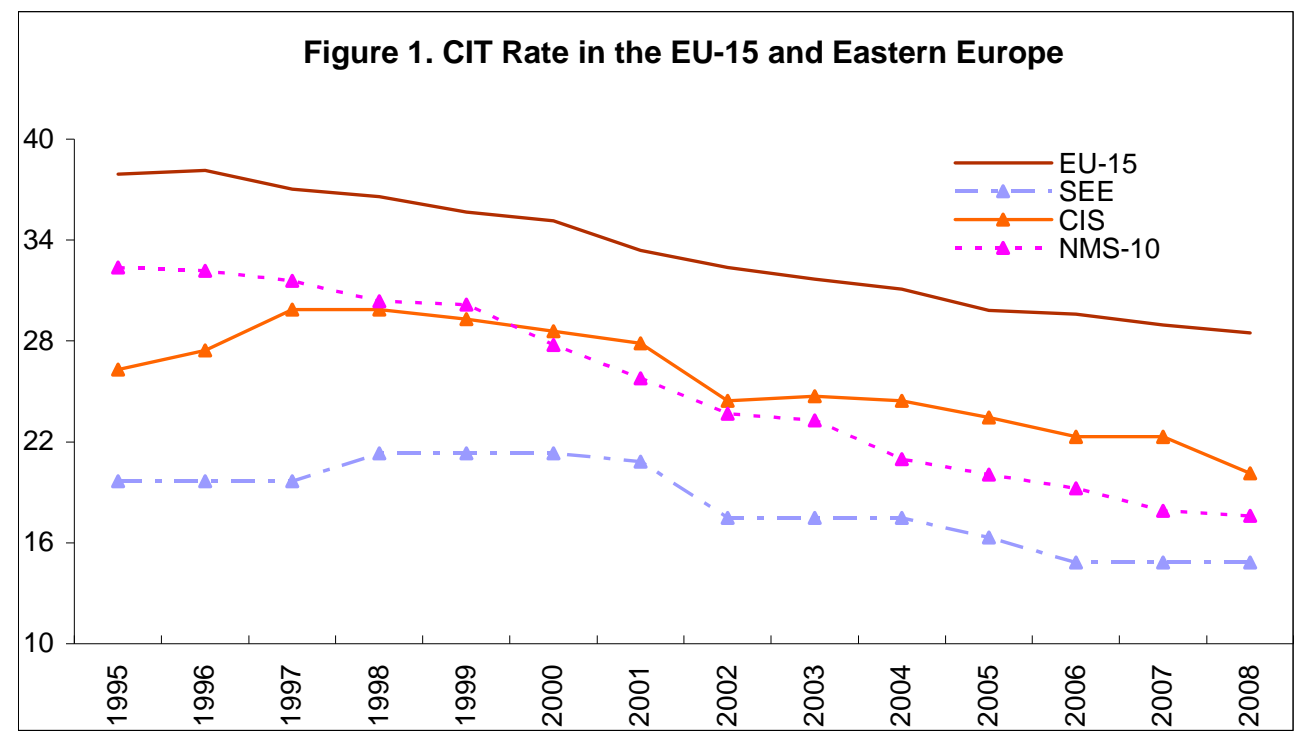

Note: unweighted average. NMS-10 include Bulgaria, Czech Republic, Estonia, Hungary, Latvia, Lithuania, Poland, Slovak Republic, Slovenia and Romania. CIS include Azerbaijan, Armenia, Georgia, Moldova, Russia, and Ukraine. SEE include Albania, Serbia, Croatia, and Bosnia and Herzegovina.

Source: PWC Worldwide Tax Summaries, IMF staff reports.

Developed countries interact in setting CIT rates. There is evidence for interdependent corporate tax setting among industrialized OECD countries and EU-15. ${ }^{6}$ Devereux, Lockwood, and Redoano (2008) estimate that during 1982-1999, among the industrialized OECD countries, a one percentage point change in other countries' weighted average

\footnotetext{
${ }^{4}$ Unless specified differently, throughout the text CIT rates mean statutory rates. Like in most literature, this paper assumes that multinationals can avoid paying taxes on repatriated dividends by channeling dividend payments from their subsidiaries to countries with the lowest, often zero, level of dividend taxation. In addition, taxes on dividends are paid only upon payment, thus allowing profits to accumulate tax free until paid out.

${ }^{5}$ Ten countries—Bulgaria, Denmark, Netherlands, Portugal, Greece, Germany, France, Spain, Albania, and Italy-will cut CIT rates in 2008. Czech Republic will gradually reduce CIT from 24 percent in 2007 to 19 percent in 2010. The new Polish government considers reducing the CIT rate to 15 percent, down from 19 percent.

${ }^{6}$ See also Mendoza and Tesar (2005), Altshuler and Goodspeed (2006) and Devereux, Lockwood, and Redoano (2008).
} 
statutory CIT rate resulted in a 0.67 percentage point change in the CIT rate in the home country. They find that the results of their model closely predict the actual fall in the CIT rates. These empirical results are confirmed by policymakers who explicitly mention tax competition as a reason for reducing CIT. ${ }^{7}$

Countries can compete for mobile capital with both rates and tax bases. The effective tax rates facing businesses depend on the statutory rates and the definition of the tax base; that is, what is considered as revenues and expenses for tax purposes. The are two measures of effective taxes: the effective average tax rate (EATR), calculated as the ratio of future tax liabilities to pre-tax financial profits (in present value terms) over the estimated duration of the investment project, determine the location of investment, while the marginal effective tax rate (EMTR), calculated as the tax wedge between the pre- and post tax return on a marginal investment project that does not yield an economic rent (the return is equal to the cost of capital), affect the size of investments. Statutory CIT rates, however, are most important for highly profitable investment and the direction of profit shifting. ${ }^{8}$

But competition over statutory CIT rates is more intense than over the tax base. Devereux, Lockwood, and Redoano (2008) find that among industrialized OECD countries competition over EMTR was weaker than over statutory rates. This was reflected in a much smaller decline in EMTR, driven by base broadening, than in statutory rates. Keen (2007) conjectures that OECD countries competed more with tax rates than with the tax base because lowering rates would prevent profit shifting, while broadening tax bases would ensure higher revenue from the less mobile corporate tax bases. More intense competition over the tax rates may also be due to the fact that small economies have a particularly strong incentive to lower the CIT rate below that of larger countries to attract profits earned abroad without losing much of the domestic tax revenue. ${ }^{9}$ In 2007, in line with the theory, small countries in Europe had indeed much lower statutory tax rates than larger countries (Figure 2).

\footnotetext{
${ }^{7}$ For instance, Roland Koch, a negotiator for the Christian Democrat party in Germany, said in 2006 that "There is no disagreement between the coalition parties that we have to tax companies differently than in past decades...(t)oday, we're exposed to international and European tax competition." Carter Dougherty, "Germany to Lower Corporate Tax Rate," International Herald Tribune-Business (November 2, 2006).

${ }^{8}$ AETR, which as the weighted average of the METR and the statutory rate, in practice closely follows the statutory rates. For highly profitable investment, marginal EATR is almost equal to the statutory rate: the higher the profits, the more the effective tax rate approaches to the statutory rate.

${ }^{9}$ Well-known tax competition models of Diamond and Mirrlees (1971), Bucovetsky (1991), and Wilson (1991) predict that smaller, open economies should have lower source-based taxes on capital income than larger countries since small countries face the most elastic corporate tax bases.
} 


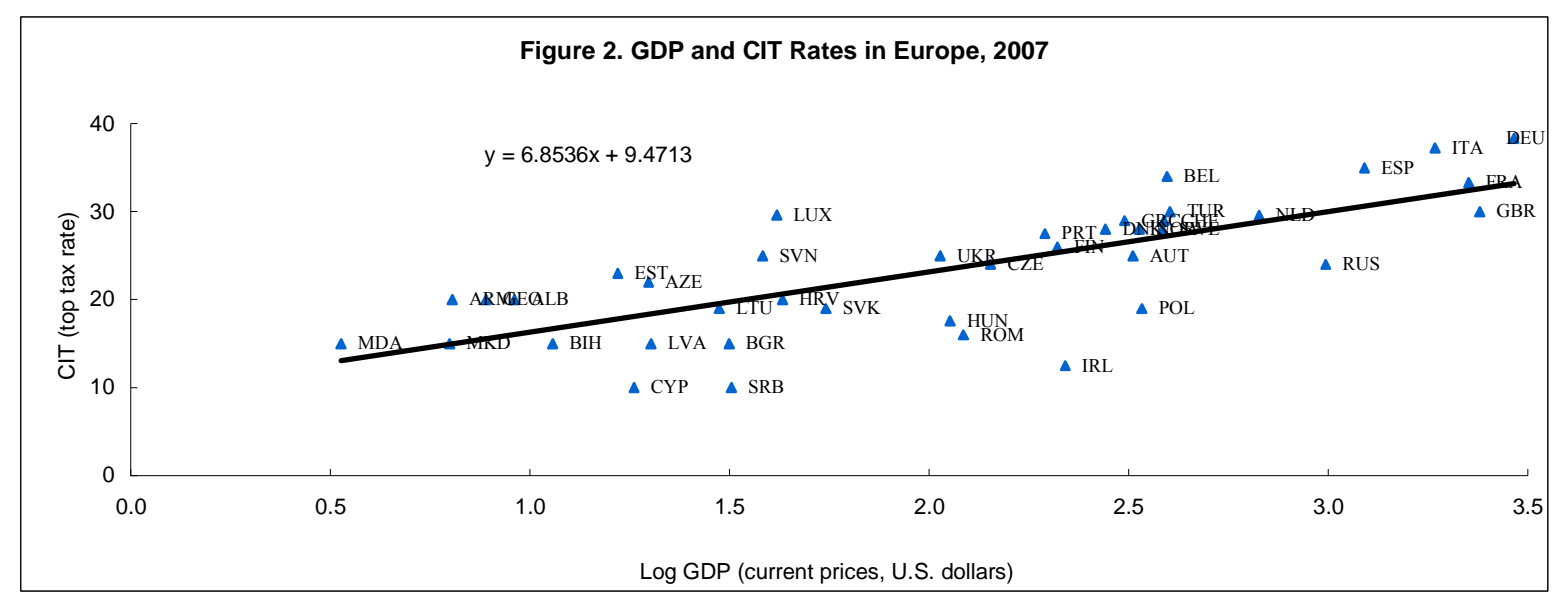

Source: WDI, Pricewaterhouse Coopers.

As a result of the more intense competition over tax rates, internationally mobile investment and profits tend to have a lower tax burden than less mobile corporate activity. This benefits multinational companies relative to domestic companies with no activities abroad (Hines 2006, Devereux, Griffith, and Klemm 2002). In addition, since multinational companies can much more freely shift profits, they can reduce the overall corporate tax burden even further. The declining CIT rates may reduce the disadvantage for domestic companies, but this may be offset by base broadening focused on taxing less mobile corporate activity with high rates to maintain the level of corporate tax revenue (Keen, 2001). There are indeed indications that large companies in Europe pay lower taxes: Nicodeme (2007) reports, on the basis of firmlevel data for 21 EU countries between 1992 and 2004, that there was a negative correlation between the firm size and the effective tax. ${ }^{10}$

\section{WHAT DRIVES TAX COMPETITION?}

There are a number of economic factors that affect the degree of tax competition. Research suggests that while openness tends to increase the intensity of tax competition, transport costs, agglomeration effects, costs of moving capital, the size of countries and similarity among countries also seem to matter, but their impact on tax rates is ambiguous: they can either decrease or increase the equilibrium CIT rate (Devereux and Loretz, 2007). Overall, however, given in particular the reduced trade costs and greater capital mobility, literature on tax competition predicts that CIT rates should be falling towards a new equilibrium (Devereux and Loretz, 2007).

Political factors also matter. In the so-called "yardstick competition," countries respond to changes in CIT in other countries because voters evaluate the performance and economic competence of their governments by comparing home tax rates to those in neighboring

\footnotetext{
${ }^{10}$ Also the smallest companies can be relatively disadvantaged: with declining CIT rates, the competitive position of some categories of small entreprises enjoying simplified tax treatment, such as, for instance, lump sum monthly tax payments, can worsen.
} 
countries (Besley and Smart, 2002). ${ }^{11}$ Countries can also lower CIT rates to send a signal to foreign investors of their business-friendly policies, ${ }^{12}$ to emulate perceived success of other countries (Estonian or Slovak tax reforms, for instance) or because they just follow a common intellectual trend. Finally, countries may reduce CIT because they might count on benefits in terms of a country's international image and visibility. ${ }^{13}$

It is difficult to delineate the specific contributions of political and economic factors to tax competition. Given the multitude and multidirectional impact of all the factors involved, no one has so far been able to estimate the extent to which political and economic factors separately contribute to competition (Devereux and Loretz, 2007, Griffith and Klemm, 2004, Nicodeme, 2006).

\section{Will The Moldovan Zero CIT INTENSIFy TAX COMPETITION IN THE REgion?}

Close correlation in the pattern of CIT rate setting in Eastern Europe seems to reflect strategic interaction (Figure 1). Similarly to OECD countries, changes in CIT rates in Eastern European countries closely followed one another during 1995-2007. The average (unweighted) CIT rate decreased by 0.74 annually in all Eastern European countries during 1995-2006 and by 1.1 percentage points during 2000-2008.

The empirical investigation confirms strategic interaction. To test the hypothesis that setting CIT rates in Eastern Europe, that is in NMS-10, CIS and SEE countries during 1995-2006 was interdependent, following Devereux, Lockwood, and Redoano (2008) we adopt a panel data approach (see Appendix 1 for details). The results of the regressions show that the changes in the average of other countries' CIT rate (weighted and unweighted) in Eastern Europe had strong statistical significance in explaining changes in CIT rates in individual countries (Table 1). The strength of the reaction function was also considerable: A one percentage point change in the average of other countries' statutory CIT rate resulted in a 0.4-0.5 percentage point change in a CIT rate in a particular country. The strength of the reaction function is similar to that reported by Devereux, Lockwood, and Redoano (2008) for OECD countries. The other tax variable - top income tax rates (PIT) - had the right sign and turned out to be statistically significant. This is because both tax rates tend to be determined

\footnotetext{
${ }^{11}$ Devereux, Lockwood, and Redoano (2008) do not find evidence for yardstick competition in corporate taxes in industrialized OECD countries. However, Keen and Lockwood (2007) find evidence that adoption of VAT in some country was more likely the higher the proportion of neighboring countries with a VAT.

${ }^{12}$ Keen, Kim, and Ricardo (2007) emphasize the importance of signaling in explaining the expansion of a flat tax on personal income in Eastern Europe.

${ }^{13}$ Estonia and Slovakia, which introduced wide ranging tax reforms in 2000 and 2004, respectively, were mentioned in international press more often than their neighbors. Under the search item "econ*" in FactivaPlus search engine, during 2000-2006 the five global leading newspapers - The Economist, Financial Times, Wall Street Journal, New York Times, and International Herald Tribune - mentioned Estonia (normalized by the size of population) more than twice as often as Latvia and Lithuania. Slovakia was mentioned twice as often as Poland.
} 
at the same time and changes in CIT and PIT rates are often coordinated to avoid tax arbitrage.

Table 1. Strategic Interaction in CIT Setting in Eastern Europe, 1995-2006

\begin{tabular}{lcc}
\multicolumn{2}{c}{ Dependent Variable: CIT rates in Eastern Europe } \\
\hline Weights & Uniform CIT average & CIT average weighted by \\
& & GDP \\
\hline Average CIT & 0.5090 & 0.4450 \\
& $(0.2600)^{\star \star}$ & $(0.2100)^{\star \star}$ \\
PIT & 0.2700 & 0.2830 \\
& $(0.0699)^{\star \star \star}$ & $(0.0740)^{\star \star \star}$ \\
GDPD & -0.0023 & -0.0032 \\
& $(0.0043)$ & $(0.0046)$ \\
GGE & 0.2610 & 0.2610 \\
& $(0.0959)^{\star \star \star}$ & $(0.0904)^{\star \star}$ \\
OPEN & -0.0441 & -0.0406 \\
& $(0.0213)^{\star \star}$ & $(0.0222)^{\star \star}$ \\
LAW & -0.1460 & -0.0345 \\
& $(0.2960)$ & $(0.3090)$ \\
adj. R-sq & & 0.51 \\
No. of observations & 0.52 & 181 \\
\hline
\end{tabular}

Notes: see Appendix 1 for details. Robust standard errors in brackets. Source: Fund staff calculations.

The regressions indicate that non-tax factors also affect CIT rate setting. The impact of government consumption (GGE) on CIT rates was positive and statistically significant because higher public spending requires at some stage higher tax revenues. The data also show that more open economies tend to set lower CIT rates. This is probably because open economies are subject to tighter competition for capital than closed economies are. This result contrasts with the one obtained by Devereux, Lockwood, and Redoano (2008) who found that for industrialized OECD countries openness played no role in determining CIT rates. ${ }^{14}$ Surprisingly, the size of countries (GDPD) — as measured by GDP — does not seem to matter, despite the theory suggesting that larger economies could afford higher CIT rates because a higher proportion of economic activity is purely domestic and thus insulated from international tax competition. Hines (2006) argues that after 1999 a similar pattern developed in Western Europe: both bigger and smaller countries reduced CIT rates at the same pace.

\footnotetext{
${ }^{14}$ Clausing (2007c) however finds that another measure of openness - ratio of outward FDI stocks to GDP matters for CIT setting in 36 OECD and European countries for the period 1979-2002, suggesting that international integration enhances responsiveness of the tax base and provides an incentive to countries to lower tax rates. But greater capital market openness is statistically significant only with $90 \%$ confidence and is not statistically significant for other specifications.
} 
This could reflect the growing role of political competition and following of the same intellectual trends. The rule of law (LAW) is not statistically significant, suggesting that even more institutionally advanced new EU member states (NMS-10) could not afford to maintain higher CIT rates than the regional average. ${ }^{15}$

The empirical results suggest that Moldova's zero CIT rate may encourage other countries in the region to reduce CIT further. These countries may reduce CIT in response to Moldova's cut to remain attractive to foreign direct investment (even though taxes are of only secondary importance to FDI, as discussed below), prevent profit shifting, and give a signal to businessmen and voters of the governments' business-friendly policies (yardstick competition).

However, the impact on other countries is not likely to be sizeable, at least in the short-term. Given that Moldova's cut will reduce the (unweighted) regional CIT rate in 2008 by 0.5 percentage points and assuming the same reaction function as for the period 1996-2006, other countries in the region are likely to reduce CIT rates by on average only $0.3-0.4$ percentage points. ${ }^{16}$ It is not inconceivable, however, that individual countries, such as those located in Moldova's neighborhood or those that are at a similar level of institutional development, could cut rates much faster than what is implied by the average. In a longer perspective, a new round of CIT cuts can - through a feedback effect - feed into new tax cutting cycles, as countries may continue to strategically respond to reductions in corporate taxation in other countries in the region. Should it be the case, the ultimate fall in the CIT rates could of course by much deeper. At this stage, it is difficult to predict if and when this process would stop.

\section{IMPLICATIONS FOR FDI, ECONOMIC EFFICIENCY, EQUITY, AND WELFARE}

Corporate taxes have only a minor impact on FDI. While at the margin lower taxes affect FDI, empirical evidence suggests that in emerging and developing countries the impact of taxes on FDI, while non-negligible, is minor compared to the quality of governance, the business climate, the quality of the infrastructure, the size of the domestic market, the distance to main markets in Western Europe, and labor costs. ${ }^{17}$ Demekas and others (2005) analyze factors driving FDI in South Eastern Europe, including Moldova. Similarly to other literature, they find that market size, geographical and cultural proximity, relative unit labor costs, infrastructure, and the trade regime matter for FDI. The corporate tax burden also

\footnotetext{
${ }^{15}$ Clausing (2007c) results are similar: she finds that EU applicant countries choose rates that are typically eight percentage points lower than other EU and OECD countries, ceteris paribus.

${ }^{16}$ The regression assumes that every country in our sample responds in the same way to the weighted average of statutory CIT rate of the other countries in the sample. This assumption is obviously not too realistic, as countries are likely to respond more to, for instance, CIT cuts in neighboring than in more distant countries or cuts in bigger than in smaller countries. While it would be ideal to estimate the response of each particular country to changes in CIT rate in Moldova, the large number of required parameters would exhaust degrees of freedom and undermine the statistical significance of results.

${ }^{17}$ See Demekas and others (2005) and McKinsey (2003).
} 
matters, but is not more significant than other factors. Dharmapala and Hines (2006) show that lower taxes matter for FDI only in well governed countries (Figure 3).

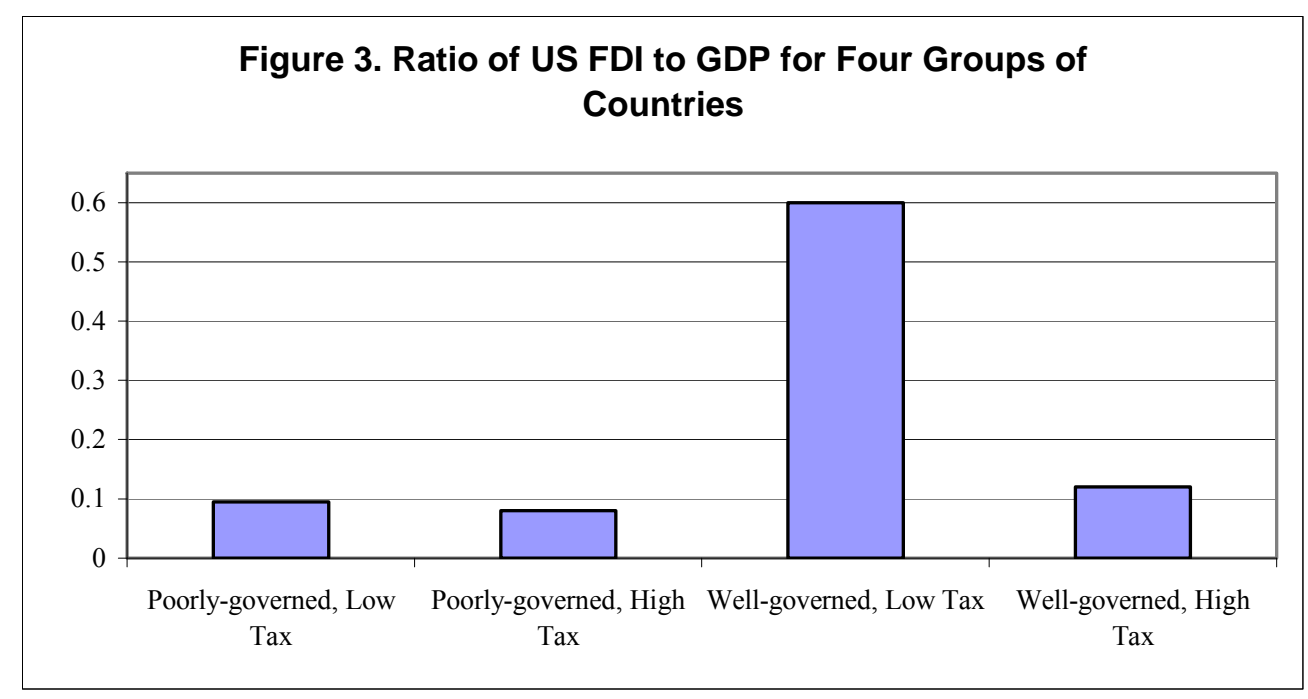

Note: The bars depict mean ratios of assets owned by US firms in 1999 to GDP for four groups of countries: those with below-median governance indices and below-median tax rates, those with belowmedian governance indices and above-median tax rates, those with above-median governance indices and below-median tax rates, and those with above-median governance indices and above-median tax rates. These medians are calculated for the 60 countries for which data on FDI by U.S. firms are available from the Bureau of Economic Analysis.

Source: Dharmapala and Hines (2006).

The zero CIT in Moldova is not likely to re-direct FDI flows in the region. To attract FDI, Moldova - and other countries in the region - should focus on improving its business environment, which - despite recent reforms - lagged behind most its regional peers as reflected in World Bank Doing Business 2008 report (drop from 90 to 92 place relative to 2007 report) and the World Economic Forum 2008 survey (drop from 86 place last year to 97 this year). ${ }^{18}$ FDI is also not likely to be affected because the current effective tax rate for most foreign companies in Moldova taking advantage of the generous tax exemptions is already close to zero. ${ }^{19}$

\footnotetext{
${ }^{18}$ B usiness env ironment is als o important for domestic investment: according to a recen $\mathrm{t}$ bu siness survey in Moldova, the cost of credit, corruption, and a lac $\mathrm{k}$ of independent court s ystem were considered to be more important obstacles to business development than taxation.

${ }^{19}$ Enterprises with investments in statutory capital or that make capital investments of over USD 250,000 are entitled to a $50 \%$ income tax reduction, effective for a period of five consecutive years. Full exemption from corporate income tax is granted to companies entities with investments of more than USD 2 million, 5 million, 10 million, 20 million or 50 million. The period of exemption depends on the amount, and can be up to seven years if certain conditions are met.
} 


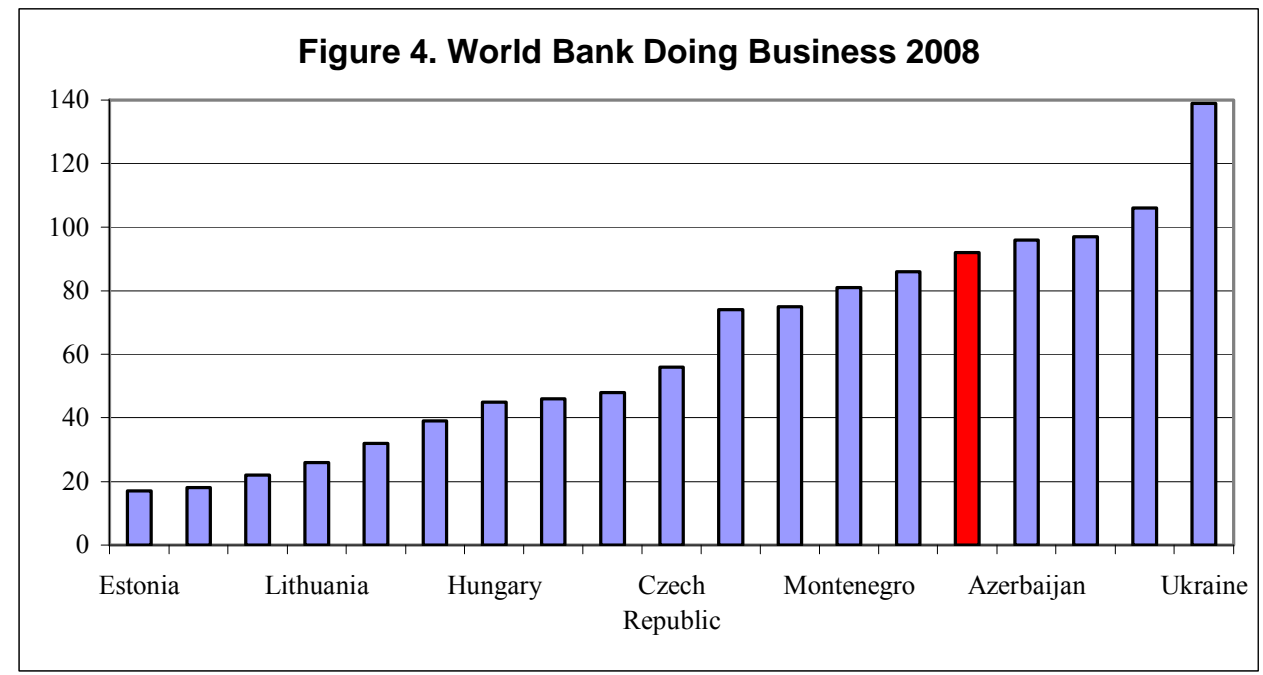

Note: Higher ranking indicates worse business climate.

Source: World Bank Doing Business 2008 report, www.doingbusiness.org

Declining CIT rates have not so far reduced revenue. Owing to base broadening, record corporate profits, improved tax administration, and possibly also lower tax evasion, cuts in CIT rates in Eastern Europe have not so far reduced tax revenue (Figure 5). In fact, they have increased from 2.1 percent of GDP in 2000 to 2.7 percent of GDP in 2006. Hines (2006) and others use this evidence to argue that tax competition does not need to lead to reduced revenue and that there is no evidence for "the race to the bottom".

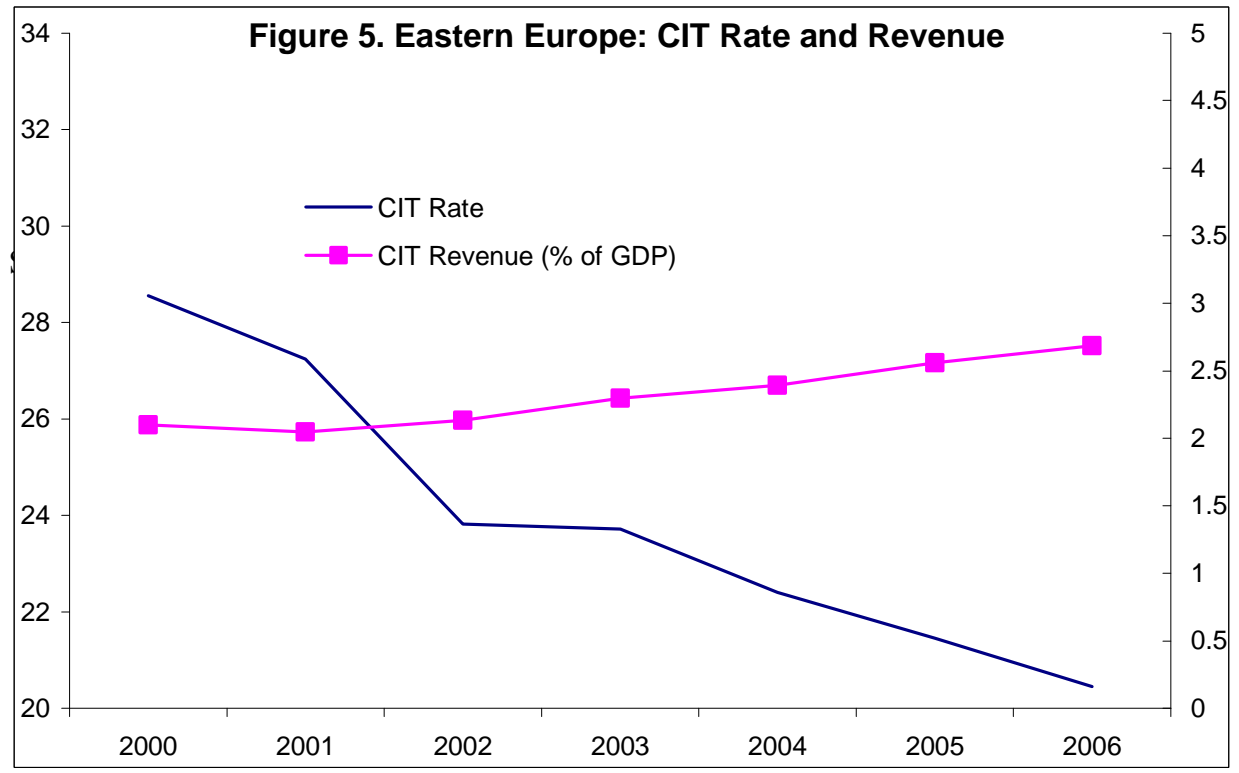

Note: Excludes oil producers Azerbaijan and Russia.

Source: PWC Worldwide Tax Summaries, IMF staff reports. 
Going forward, however, corporate tax revenue are likely to start falling if CIT rates continue to decline. This may happen for the following three reasons:

- After almost two decades of reforms, there is now a much smaller scope for improvements in tax administration, further base broadening, and reductions in tax evasion (European Commission, 2007b). Figure 6 provides evidence that in eight NMS countries the tax base was substantially broadened, as reflected in the declining difference between average statutory and effective tax rates.

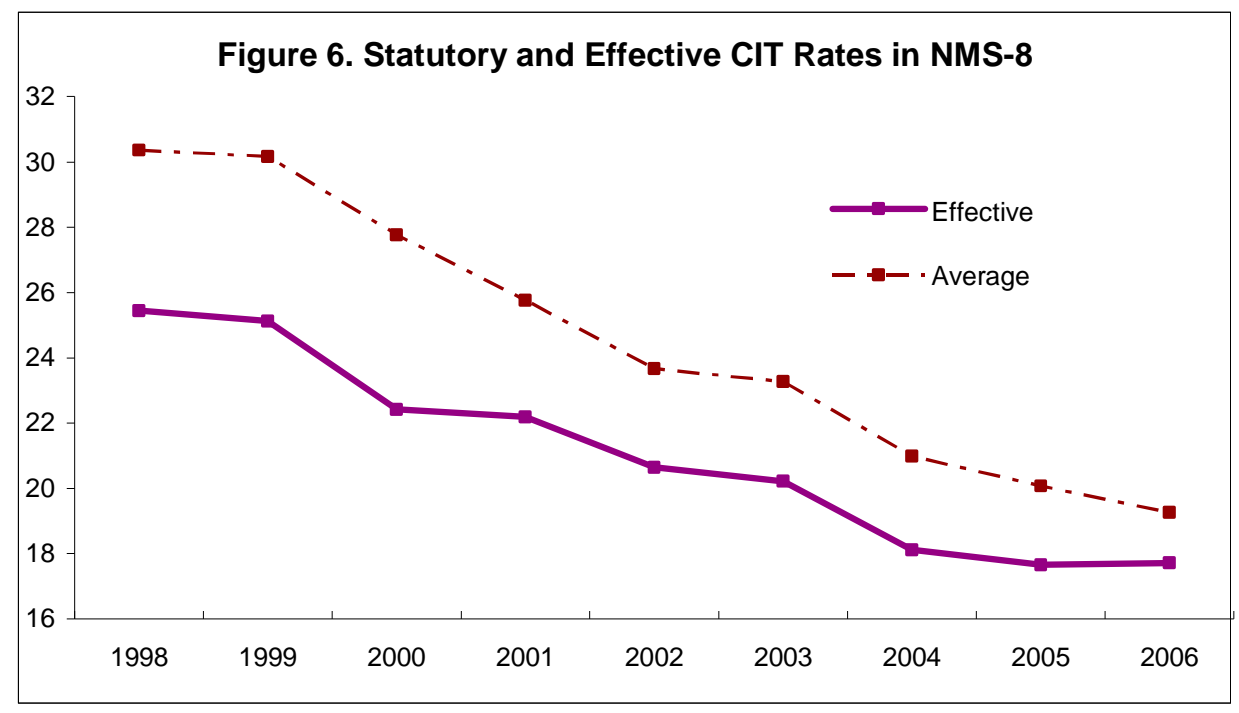

Source: OECD (2007) and Fund staff calculations.

- $\quad$ The share of corporate profits in GDP, reflecting growing profitability of enterprises in Eastern Europe and declining shares of labor income in GDP, measured by the ratio of gross operating surplus to GDP, is now above the historical average and may gradually decline to the historical trend (Figure 7$) ;{ }^{20}$

- $\quad$ CIT rates may soon be below the revenue maximizing rate. The revenue maximizing rate for corporate tax rates in OECD and EU countries, which reflects the parabolic relationship between corporate tax revenues and tax rates, is estimated to range from 26 to 32 percent (Figure 8). ${ }^{21}$ While there are no similar studies for Eastern Europe, given weaker tax administration, higher openness, and larger scope for tax evasion,

\footnotetext{
${ }^{20}$ The fact that despite substantial cuts in statutory tax rates have not led to revenue losses in revenue presents something of a puzzle for both Western and Eastern Europe. See Clausing (2007a), Devereux and Klemm (2002), Keen (2007), Devereux (2007).

${ }^{21}$ Clausing (2007c) estimates the revenue maximizing rate for corporate tax rates in 36 OECD and EU countries during 1979-2002, including NMS-10. She finds that the average revenue maximizing rate is 32 percent, but is lower for smaller and more open economies. Brill and Hasset (2007) find that for industrialized OECD countries the revenue maximizing corporate tax rate declined to 26 percent in 2006 from 34 percent in the late 1980s. It is important to note that the revenue maximizing rate does not imply that this is the optimal tax rate.
} 
the revenue maximizing rate is likely to be lower. The average CIT rate in 2008 in Eastern Europe at 17.6 percent might already be close to the revenue maximizing rate. As a result, the positive supply side effects of CIT cuts are likely to be quickly diminishing and - given the parabolic shape of the curve - tax revenues can start falling at an increasing rate.

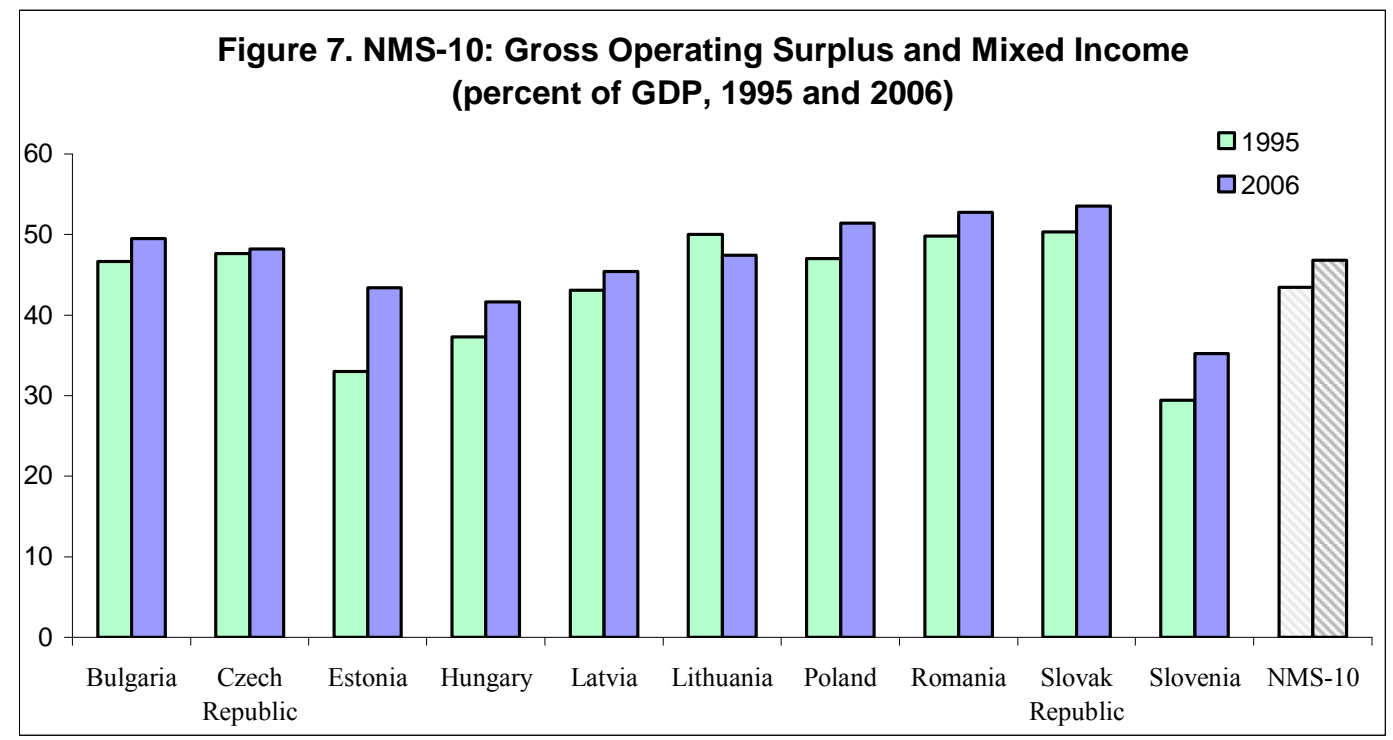

Note: Gross operating surplus is defined as the surplus accruing from production before taking account of any interest, rent or similar charges payable or received on financial or tangible non-produced assets borrowed, rented, or owned by the enterprise.

Source: Eurostat and Ameco database.

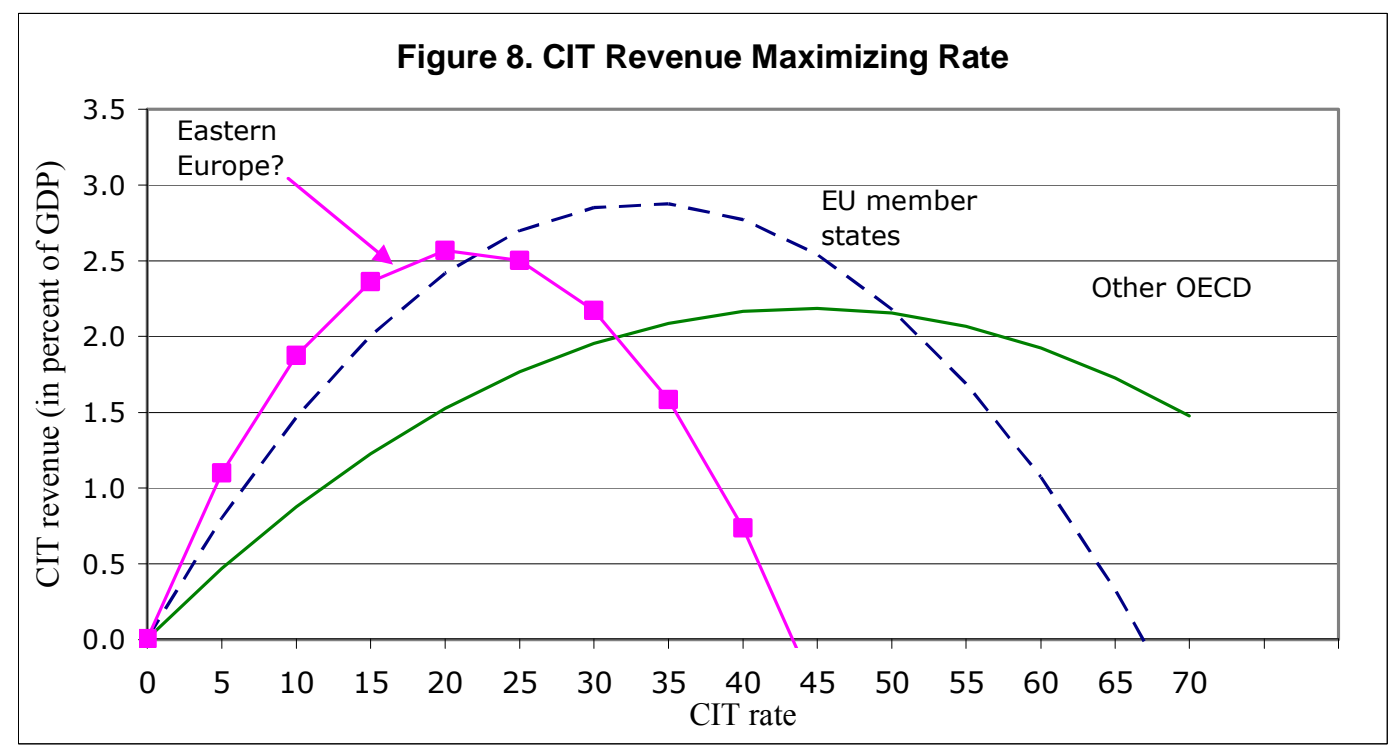

Note: Based on a data set of 36 OECD and European countries between 1979 and 2002 .

Source: Clausing (2007c) for the EU-25 and other OECD. 
Lower CIT rates may also reduce revenue from personal income tax. Since positive CIT rates are meant to prevent individual tax payers from incorporating to lower tax liabilities, lower CIT is likely to increase pressure on reducing personal income tax rates. ${ }^{22}$ Indeed, during the last decade CIT and PIT rates have gone hand in hand, suggesting that PIT rates are likely to follow reductions in CIT (Figure 9). In addition, increasing mobility of labor within the EU may also intensify competition in personal taxation to prevent tax-induced labor migration. ${ }^{23}$ Finally, competition in personal taxes on their own is also intensifying, as reflected in the expansion of flat taxes on personal incomes in Eastern Europe. As a result, overall revenue from direct taxes can decrease further.

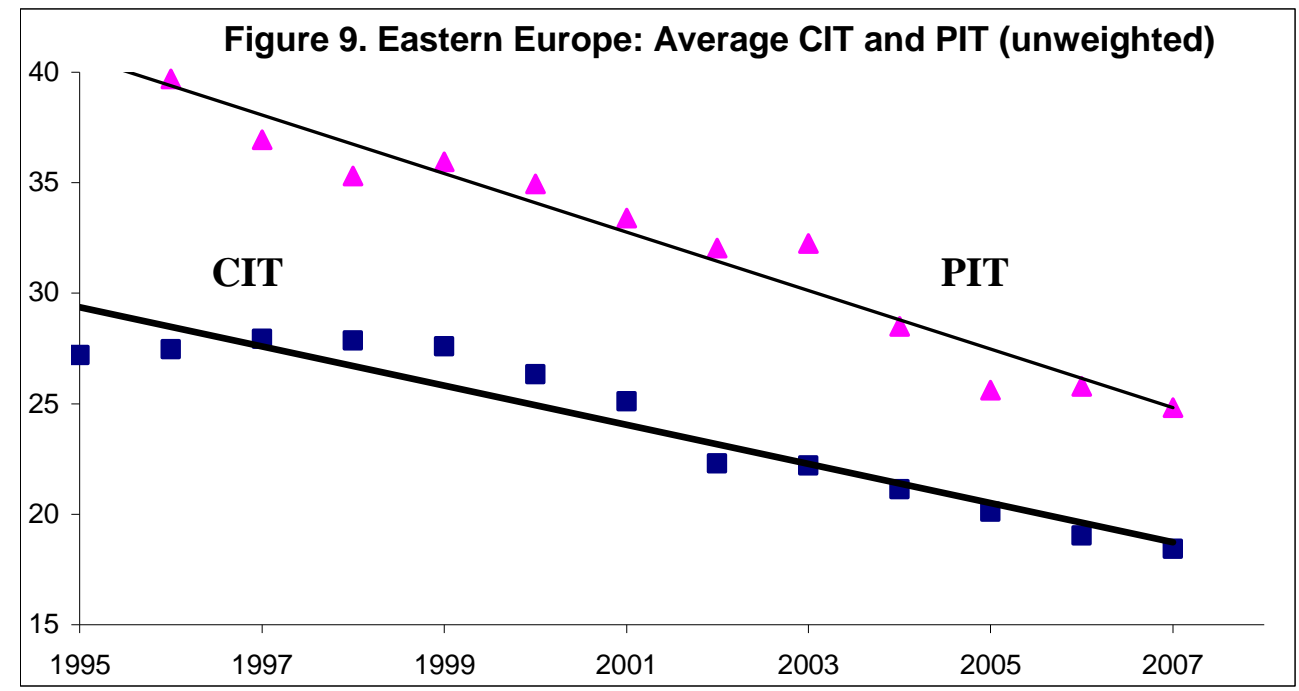

Source: PWC Worldwide Tax Summaries, IMF staff reports.

However, revenue losses could be partially offset by profit shifting. There is a large literature documenting significant profit shifting in Europe among multinational companies. ${ }^{24}$ Huizinga and Leuven (2007) argue that profit shifting by multinationals leads to a substantial redistribution of national corporate revenues, especially at the expense of Germany and to the benefit of countries with the lowest tax rates such as Hungary. They estimate that the elasticity of reported profits by multinationals with respect to the top statutory rate amounts to 1.43 percent, that is a one percentage point relative increase in the statutory rate reduces reported profits by 1.43 percent. Bartelsman and Beetsma (2003) provide similar results: in

\footnotetext{
${ }^{22}$ De Mooij and Nicodeme (2006) argue that the remarkably stable CIT revenues in EU-15 despite declining CIT rates are partly due to shifts from the personal to the corporate tax base as individuals increasingly incorporated. Their simulations suggest that between $10 \%$ and $17 \%$ of corporate tax revenue in EU-15 can be attributed to that kind of income shifting. Gordon and Slemrod (2000) and Fuest and Weichenrieder (2002) find similar evidence.

${ }^{23}$ By 2011, all EU-15 members have to lift the remaining restrictions on free movement of labor from the new EU member states (longer periods for Bulgaria and Romania).

${ }^{24}$ Bartelsman and Beetsma (2003), Huizinga and Leuven (2007), Huizinga, Leuven, and Nicodeme (2007).
} 
EU-15 a unilateral one percentage point relative increase in the tax rate leads to a at least a 3 percent fall in reported corporate profits. Lower rates in Eastern Europe, unless followed by similar cuts in Western Europe, could thus increase profit shifting from Western Europe and increase overall tax revenue. The size of potential profit shifting and tax revenue gains is, however, difficult to estimate and more research is needed. ${ }^{25}$

And by faster long-term growth. To the extent that declines in corporate taxation improve the efficiency of tax systems (see below) and limit wasteful government spending, long-term growth could accelerate and corporate tax revenue could increase (Hines, 2006). However, Mendoza, Milesi-Ferretti, and Asea (1995), who test the Harberger's superneutrality conjecture, show that while higher tax rates on capital and labor income are associated with lower private investment levels, and higher consumption taxes result in higher investment, the overall impact on growth is likely to be small.

Lower tax revenue from CIT and PIT, unless offset by expenditure cuts, will need to be replaced with revenue from other taxes. ${ }^{26}$ During 2000-2006, while revenue from direct taxes, PIT and CIT, in NMS-10 and CIS was roughly stable, public spending was increasingly financed with revenue from VAT (Figure 10). If revenue from direct taxes starts falling, the growing role of VAT as a source of revenue is likely to continue. Revenues from social security contributions might also need to increase to finance aging-related expenditures.

\footnotetext{
${ }^{25}$ German government estimates that the 2008 corporate tax reform which cuts CIT rate from 38 to 29 percent will stimulate repatriation of profits generating 5 billion Euro ( 0.2 percent of GDP) of additional revenue (IMF, 2008). Clausing (2007b) estimates that the tax avoidance by US multinationals cost US Treasury about $\$ 54$ billion in lost revenue in 2002, 37 percent of total corporate tax revenue of $\$ 148$ billion in that year.

${ }^{26}$ In addition, overall tax revenue is likely to decline owing to the work of "fiscal termites," such as the expansion of tax-free electronic commerce, improving ability of international companies to shift profits to low tax destinations, increasing mobility of labor, and electronic money (Tanzi, 2002). Climate change may add to the weakening of tax bases owing to its negative impact on output and productivity and higher energy costs. However, revenue losses could be partially offset by revenues from new environmental taxes, such as those on carbon emissions.
} 
Figure 10. Tax Revenue by Source in NMS-10 and CIS (percent of total revenue)
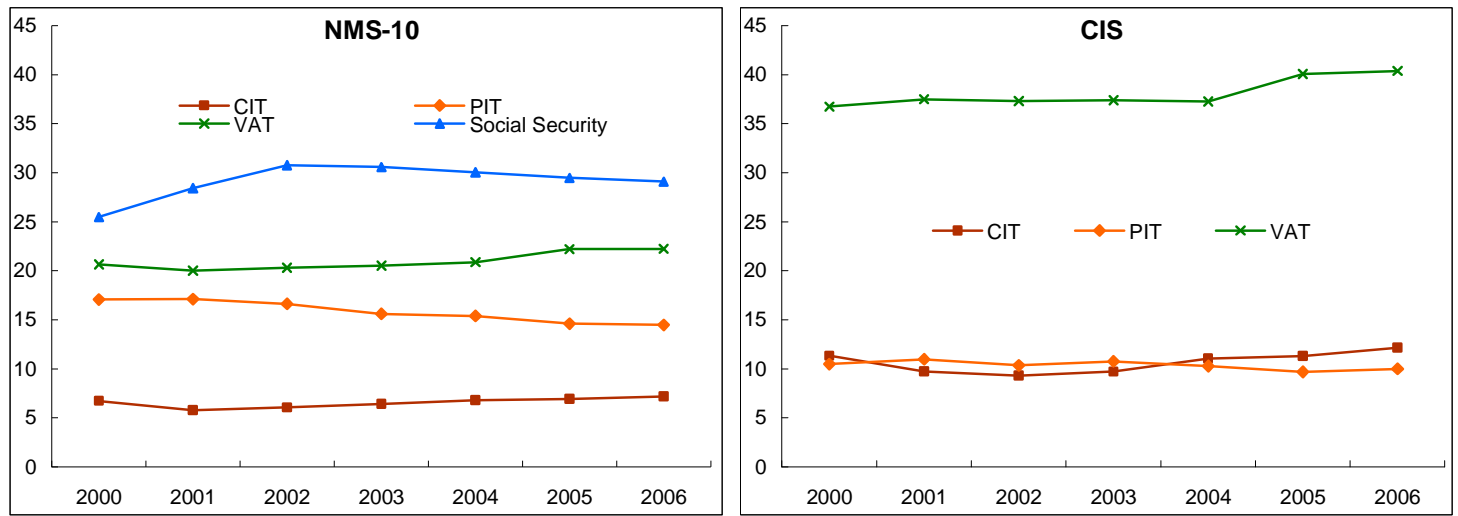

Note: For CIS, oil-producers Russia and Azerbaijan are excluded.

Source: Eurostat and IMF staff reports.

Increasing role of taxes on consumption is likely to increase economic efficiency. Tax efficiency is highest in tax systems which minimize distortions to the location and scale of investment, to the sources and uses of finance, and to the choice of legal form. Optimal tax literature suggests that overall deadweight costs of taxation and thus economic efficiency is generally higher if taxes are levied on most inelastic cash flows and least mobile bases, such as labor, consumption, and real estate. This is particularly relevant for small, open economies, such as Moldova, which face the most mobile capital and - in theory - should not tax capital at all (Keen and Simone, 2004). The shift towards VAT may hence increase overall economic efficiency of tax systems.

But it may be partly offset by more distorting labor taxes. Recent empirical literature suggests that labor tends to be more elastic than previously thought and therefore taxing labor can be as distortionary as taxing capital (Penalosa and Turnovsky, 2005). Taxes on labor, such as social security contributions, could be even more distortionary than taxes on capital if one considers the negative impact of taxes on labor on the level of employment and thus on growth. ${ }^{27}$ World Bank (2007) argues that a high tax wedge, which reflects combined burden of social security contributions and personal income taxes, is one of the major factors explaining while employment ratios in most NMS-10, especially for the low-skilled, are lower than the EU-15 average.

The shift in the composition of tax revenue may have adverse distributional consequences. VAT and social security payments tend to be regressive, particularly when the latter are capped at a certain multiple of the salary. ${ }^{28}$ In addition, high payroll taxes tend to

\footnotetext{
${ }^{27}$ Peñalosa and Turnovsky (2005) argue that in developing countries with a large informal economy taxing capital more heavily than labor income could be optimal.

${ }^{28}$ In practice, VAT is often only mildly regressive, as argued by Moore (2005) for Slovakia, Dalsgaard (2008) for the Czech Republic and Newhouse and Zakharova (2007) for the Philippines. Moreover, given the fact that richer households tend to find it easier to evade taxes on capital than on consumption, increasing taxation of the latter can be progressive. Furthermore, poorest households in Eastern Europe tend to procure goods in informal markets, where goods and services are not taxed at all. Finally, VAT helps reduce intergenerational inequities as it taxes both past and present earnings (Dalsgaard, 2008).
} 
disproportionately discourage employment of low-skilled labor from the poorest households (World Bank, 2007).To the extent that the declining corporate tax revenue is replaced with revenue from VAT and payroll taxes, the progressivity of tax systems may diminish. ${ }^{29}$

The size of any negative distributional effects is hard to establish, but is not likely to be substantial. While VAT and payroll taxes are likely to be negative for equity, it is not clear who benefits from a lower burden of the corporate tax: lower taxes on capital may either increase real wages and/or increase returns for capital owners. ${ }^{30}$ In any case, the distributional effects of the shift in the composition of tax revenue is not likely to be large, given that CIT revenue only slightly exceeds 5 percent of total revenue in NMS-10, CIS and SEE (Figure 10). In the end, the degree of progressivity is dependant on both taxes and expenditures, where the former tend to have only a limited role

It is not clear how corporate taxation affects social welfare through public spending. Welfare increases if government expenditures have utility or production benefits higher than the deadweight loss from taxation. Keen (2007) argues that the citizens' welfare increases if and only $\lambda<M D L /(1+M D L)$, where $\lambda$ is the proportion of public expenditure that is wasted and $M D L$ is the marginal deadweight loss from raising an additional unit of revenue from corporate taxes. If the marginal deadweight loss from corporate taxation is, say, 15 percent, and if the proportion of waste in marginal public expenditure does not exceed 13 percent, then welfare would increase if CIT rates stopped declining (Keen, 2007). ${ }^{31}$

Tax coordination could prevent CIT rates from falling below the welfare-optimal level. Tax coordination could take a form of an explicit agreement among countries to coordinate changes in corporate taxes (or any taxes for that matter) or through setting minimum CIT rates. The EU already set a precedent: it requires that in all member states the standard VAT rate does not fall below 15 percent. Minimum rates could limit any 'race to the bottom,' while leaving some leeway for national discretion in tax-setting. Even countries required to raise tax rates could benefit from the adoption of a minimum tax: this is because when they raise their rates, countries with high tax rates would be less threatened by low rates in other countries and thus be more likely to set higher rates than in a scenario without a minimum tax. The higher rates in high tax countries would reduce the damage to countries forced to raise their rates. In fact, they could even benefit from it. In this way, imposing a minimum rate may be Pareto-improving (Keen, 2007).

\footnotetext{
${ }^{29}$ Since CIT tends to be a much more important source of funding for social welfare spending in developing countries, they can be particularly exposed to adverse distributional impact of declining CIT revenues (Keen and Simone, 2004).

${ }^{30}$ Kotlikoff and Summers (1987) argue that part of the burden of corporate taxation can be shifted to consumers in the form of higher prices, and the extent of this shifting is hard to estimate. Piketty and Saez (2006) argue that the the progressivity of the U.S. federal tax system for top income earners has declined dramatically since the 1960 s mostly due to a drop in the corporate tax burden.

${ }^{31}$ Keen and Marchland (1997) argue that competition for mobile capital may also distort the composition of public spending, with too much spending on infrastructure and too little on items benefiting the consumers "too many airports, not enough libraries."
} 
But gains from tax coordination - if any-would not be substantial. Mendoza and Tesar (2005) argue that any gains in tax coordination among the biggest EU countries would be modest: it could add only up to 0.26 percent to lifetime consumption and such small benefits may not exceed the costs of tax coordination. Likewise, Brochner and others (2006) in their study of tax coordination in EU-25 find only modest aggregate welfare gains owing to tax coordination and caution that specific features of any coordination mechanism are important and economic gains can not be taken for granted. Sorensen (2004) estimate that EU-average welfare gains from tax coordination could amount to 0.95 percent of GDP (higher if marginal public revenue is spent on public goods rather than on social transfers). ${ }^{32}$ There are no similar studies for Eastern Europe, although Keen (2007) argues that the case for tax coordination in developing countries could be stronger given the larger impact of CIT rates on revenue. ${ }^{33}$ But all of this discussion ignores the fact that tax coordination could be very difficult politically and be open to competition from countries from outside the agreement. ${ }^{34}$

\section{Conclusions}

Further economic integration in Europe, increasing capital mobility, and the fact that it will be increasingly difficult and costly to maintain complex national taxes on ever more mobile capital, are likely to continue to drive the decline in CIT rates in Eastern Europe andthrough increased tax competition pressures - also in Western Europe. The paper provides the first empirical evidence that there is a strategic interaction in setting the CIT rates in Eastern Europe, and by implication that the Moldovan zero CIT may encourage a further decline in CIT rates in the region.

Falling CIT rates are not likely to lead to a significant re-direction of FDI flows in CIS and SEE countries, as other factors such as the institutional environment are much more important for attracting FDI (taxes could, however, be relatively more important for attracting FDI into new EU member states). But, as discussed above, CIT cuts in any particular country are likely to be followed by other countries in the region, further reducing the relative importance of taxes. To tangibly increase FDI, Moldova and other countries in the region should accelerate structural reforms aimed at improving the quality of the business climate, including through enhancing the protection of property rights, reducing corruption, and improving the quality of public services. Lower CIT, while helpful at the margin, will not be a panacea.

\footnotetext{
${ }^{32} \mathrm{He}$ also finds that welfare gains for the poorest households would be higher than for the median voter. See also Nicodème (2006).

${ }^{33}$ Keen (2007) argues, however, that while governments do not cooperate explicitly, given that the tax-setting game between them is played repeatedly, they may find ways to cooperate tacitly and so avoid inefficiencies.

${ }^{34}$ See Sørensen (2004), Eggert and Haufler (2006), and Brøchner and others (2006). The latter discuss the conflicts of interest which make further corporate (or any other) tax coordination in the EU rather unlikely at the present stage of political integration. They argue, for instance, that the unanimity rule for tax policy decisions within the EU has made it very difficult to reach any significant degree of coordination of corporate income taxation.
} 
Falling CIT rates are likely to eventually reduce revenue from taxes on corporate income in the future, which - unless offset by cuts in expenditures - will need to be replaced with revenue from taxes on consumption and labor. While the shift towards taxing consumption, mainly VAT, may increase economic efficiency, increasing taxation of labor may decrease it. The shift in the composition of taxation may also have negative distributional effects, although the impact is not likely to be significant given the small share of corporate tax revenue in total tax revenues in Eastern Europe. In any case, any such negative impact could be offset by, for example, improved targeting of social assistance. In general, structural reforms aimed at increasing the efficiency of public spending could lower the incentive for reducing CIT rates, as long as government expenditures achieve utility or production benefits higher than the deadweight loss from taxation.

There is no consensus on whether tax competition and resulting cuts in CIT rates are beneficial or not. Some argue that lower rates will improve the country's competitiveness and lower revenue will force governments to eliminate wasteful expenditure, thus contributing to faster long-term growth. However, others counter that tax competition has already gone too far, undermining public investment and social spending. It therefore needs to be controlled, through, for instance, European-wide tax coordination. But benefits of corporate tax coordination may not be significant, particularly relative to its cost. Tax coordination may also be difficult to implement because of political sensitivity as well as the fact that tax coordinating countries may find themselves vulnerable to tax competition from countries outside the agreement. As of now, there is no consensus in the EU or in Eastern Europe about the desirability of limiting tax competition, not to mention the details of any agreement.

Without tax coordination, can corporate taxation ultimately disappear? On the one hand, competition may stop if governments become reluctant to give up all corporate tax revenue. They may also realize that declining corporate taxation will affect foreign and domestic investment less and less and thus further cuts would be unproductive. On the other hand, however, there will always be countries with an incentive to lower their corporate tax rates below those of their neighbors to attract investment and profits. And voters may continue to demand ever lower taxes and associate economic competence with tax-reducing reforms, causing governments to continue reducing taxes. On balance, it is unclear what exactly could stop corporate taxes from falling further. Thus it can not be excluded that corporate tax rates could ultimately decline to zero, particularly in small countries facing the same incentives as Moldova. 


\section{References}

Altshuler, R. and Goodspeed, T. 2006. "Follow the Leader? Evidence on European and U.S. Tax Competition," December.

Bartelsman, E.J. and Beetsma, R. 2003. "Why Pay More? Corporate Tax Avoidance Through Transfer Pricing in OECD countries," Journal of Public Economics 87, 2225-2252.

Besley, T. J. and Smart, M. 2002. "Does Tax Competition Raise Voter Welfare?" CEPR Discussion Papers 3131.

Brill, A. and Hassett, K. A. 2007. "Revenue-Maximizing Corporate Income Taxes: The Laffer Curve in OECD Countries," AEI Working Paper, July.

Brøchner, J., Jensen, J., Svensson, P., and Sørensen, P.B. 2006. ”The Dilemmas of Tax Coordination in the Enlarged European Union," CESifo Working Paper No. 1859. November.

Bucovetsky, S. 1991. “Asymmetric Tax Competition,” Journal of Urban Economics 30, 167-181.

Clausing, K. 2007a "Corporate Tax Revenues in OECD countries," International Tax and Public Finance, 14:115-133.

Clausing, K. 2007b. "Multinational Firm Tax Avoidance and U.S. Government Revenue," Wellesley College Working Paper.

Clausing, K. 2007c. "Closer Economic Integration and Corporate Tax Systems," manuscript, November.

Dalsgaard, T. 2008. "Tax and Welfare Reforms in the Czech Republic: Structural Implications and Challenges," IMF Working Paper 08/52.

Demekas, D.G., Horváth, B., Ribakova, E., and Wu, Y. 2005. "Foreign Direct Investment in Southeastern Europe: How (and How Much) Can Policies Help?" IMF Working Paper No. 05/110.

De Mooij, R.A. and Nicodème, G. 2006. "Corporate Tax Policy, Entrepreneurship and Incorporation in the EU," CPB Netherlands Bureau for Economic Policy

Anal ysis, December.

Devereux, M. P. 2007. "Taxes in the EU New Member States and the Location of Capital and Profit,” Working Paper 07/03, Said Business School.

Devereux, M.P. and Griffith, R. 2002. "The impact of corporate taxation on the location of capital: A review," Swedish Economic Policy Review 9, 79-102. 
Devereux, M.P., Griffith, R., and Klemm, A. 2002. "Corporate Income Tax Reforms and International Tax Competition,” Economic Policy 35, pp. 451-495.

Devereux, M.P. and Klemm. A. 2004. "Measuring Taxes on Income from Capital," in P. Birch Sørensen (ed.), Measuring the Tax Burden on Capital and Labor, Cambridge, USA: MIT Press, 2004, 73-98.

Devereux, M.P., Lockwood, B., and Redoano, M. 2008. "Do Countries Compete Over Corporate Tax Rates,” Journal of Public Economics 92, pp.1210-1235.

Devereux, M.P., Loretz, S. 2007. "Determinants of Bilateral Effective Tax Rates: Empirical Evidence from OECD Countries," Fiscal Studies 29, pp.227-249.

Dharmapala, D. and Hines Jr., J. R. 2006. "Which Countries Become Tax Havens?" Available at SSRN: http://ssrn.com/abstract $=952721$

Diamond, P.A., and Mirrlees, J.A. 1971. "Optimal Taxation and Public Production II: Tax Rules.” American Economic Review, Vol. 61(3), pp. 261-78, June.

econ.hunter.cuny.edu/ goodspeed/papers/altshuler_goodspeed_dec063.pdf.

Eggert, W. and Haufler, A. 2006. "Company Tax Coordination cum Tax-Rate Competition in the European Union," FinanzArchiv/Public Finance Analysis 62:579-601.

Engel, E., Galetovic, A., and Raddatz, C.E. 1999. "Tax and Income Distribution in Chile: Some Unpleasant Redistributive Arithmetic," Journal of Development Economics 59, June, pp. 155-92.

European Comission. 2007. "Taxation Trends in the European Union. 2007 Edition."

European Commission. 2006. "Structures of the Taxation Systems in the European Union."

Fuest, C. and Weichenrieder, A. 2002.Tax Competition and Profit Shifting: On the Relationship Between Personal and Corporate Tax Rates," CESifo Working Paper No. 781.

Garretsen, H. and Peeters, J. 2007. "Capital Mobility, Agglomeration and Corporate Tax Rates: Is the Race to the Bottom for Real?," CESifo Economic Studies.

Gigineishvili, N. 2002. "Pass-Through from Exchange Rate to Inflation: Monetary Transmission in Georgia," Proceedings, Economic Series, Georgian Academy of Science, Vol. 10, No. 3-4. pp. 214-232.

Griffith, R. and Klemm, A. 2004. "What Has Been the Tax Competition Experience of the Past 20 Years," IFS Working Papers W04/05.

Hajkova, D. G., Nicoletti, L., Kwang-Yeol Yoo. 2006. "Taxation, Business Environment and FDI Location in OECD Countries," OECD, Working Papers 502. 
Hines Jr., J.R. 2006. “Will Social Welfare Expenditures Survive Tax Competition?” Oxford Review of Economic Policy, Vol 22. No 3.

Hines Jr., J. R. 2007. “Corporate Taxation and International Competition” in: A. Auerbach, J.R. Hines Jr and J. Slemrod (eds) Taxing Corporate Income in the $21^{\text {st }}$ Century, Cambridge University Press.

Huizinga, H., and Leuven, L. 2007. "International Profit Shifting within European Multinationals," Centre for Economic Policy Research Discussion Paper No. 6048, January.

Huizinga, H., Leuven, L. and Nicodème, G. 2007. "Capital Structure and International Debt Shifting," IMF Working Paper 07/39.

IMF, 2008. “Germany-Article IV,” International Monetary Fund, forthcoming.

Keen, M. 2007. "Tax Competition," in: S Durlauf and Lawrence Blume (eds) New Palgrave Dictionary of Economics, Macmillan: Basingstoke, forthcoming.

Keen, M. 2001. "Preferential Regimes Can Make Tax Competition Less Harmful?” National Tax Journal, 54(4), 757-62.

Keen, M., Kim, Y., and Varsano, R. 2007. “The 'Flat Tax(es)': Principles and Evidence. International Tax and Public Finance," IMF Working Paper 06/218.

Keen, M. and Lockwood, B. 2007. "The Value-Added Tax: Its Causes and Consequences," IMF Working Papers 07/183.

Keen, M. and Marchand, M. 1997. "Fiscal Competition and the Pattern of Public Spending," Journal of Public Economics 66, pp. 33-53.

Keen, M. and Simone, A. 2004. "Tax Policy in Developing Countries: Some Lessons from the 1990s, and Some Challenges Ahead," in: S. Gupta, B. Clements and G. Inchauste (eds): Helping Countries Develop: The Role of the Fiscal Policy. Washington DC: International Monetary Fund, pp. 302-352.

Kotlikoff, J., and Summers, L.H. 1987. “Tax Incidence” in: A. Auerbach and M. J. Feldstein, (eds.), Handbook of Public Economics, Amsterdam: North Holland, pp.1043-94.

Meade, J. 1978. "The Structure and Reform of Direct Taxation," London: Allen and Unwin. McKinsey. 2003. "New Horizons: Multinational Company Investment in Developing Economies.” McKinsey Global Institute Publication.

Mendoza, E.G. and Tesar, L.L. 2005. "Why Hasn't Tax Competition Triggered a Race to the Bottom? Some Quantitative Lessons from the EU," Journal of Monetary Economics, W. 52, pp. 163-204. 
Mendoza, E.G, Milesi-Ferretti, G.M. and Asea, P. 1995. "Do Taxes Matter for Long-Run Growth? Harberger's Superneutrality Conjecture," IMF Working Paper WP/95/79.

Newhouse, D. and Zakharova, D. 2007. "Distributional Implications of the VAT Reform in the Philippines," IMF Working Paper 07/153.

Nicodeme, G. 2007. "Do Large Companies Have Lower Effective Corporate Tax Rates? A European Survey?” Solvay Business School Working Paper 07-001.

Nicodeme, G., 2006. "Corporate Tax Competition and Coordination in the EU: What Do We Know? Where Do We Stand?" EUROPEAN ECONOMY. ECONOMIC PAPERS. No. 250. June.

OECD. 2007. "Effective Tax Rates in an Enlarged European Union,” Working Party No. 2 on Tax Policy Analysis and Tax Statistics, CTPA/CFA/WP2(2007)14, OECD, May.

Peñalosa, G. and Turnovsky, S. 2005. "Second-best Optimal Taxation of Capital and Labor in a Developing Economy," Journal of Public Economics, 89: 5-6, pp. 1045-1074, June.

Piketty, T. and Saez, E. 2006. "How Progressive is the US Federal Tax System? A Historical and International Perspective," NBER Working Paper No. 12404. August.

Slemrod, J. 2004. “Are Corporate Tax Rates, or Countries, Converging?” Journal of Public Economics 88, pp.1169-1186.

Sørensen, P.B. 2004. "International Tax Coordination: Regionalism versus Globalism?” Journal of Public Economics 88, pp. 1187-1214.

Sørensen, P.B. 2007. “Can Capital Income Taxes Survive? And Should They?” CESifo Economic Studies, Vol. 53, 2/2007, pp. 172-228.

Tanzi, T. 2000. "Globalization, Technological Developments, and the Work of Fiscal Termites," IMF Working Paper 00/181.

Wilson, J.D. 1999. “Theories of Tax Competition,” National Tax Journal 52, pp. 269-304.

Winner, H. 2005. "Has Tax Competition Emerged in OECD Countries?” International Tax and Public Finance 12, pp. 667-687.

World Bank. 2007. "Fiscal Policy and Economic Growth. Lessons for Eastern Europe and Central Asia,” Editors: C. Gray, T. Lane, and A. Varoudakis. July.

Zodrow, G.R. 2003. "Tax Competition and Tax Coordination in the European Union" International Tax and Public Finance 10, pp. 651-671. 


\section{Appendix I}

\section{Data description}

The empirical results are based on an unbalanced panel of countries spanning the period from 1995 to 2006. Countries included in the sample are Albania, Armenia, Belarus, Bulgaria, Bosnia, Croatia, the Czech Republic, Estonia, Georgia, Hungary, Latvia, Lithuania, Moldova, Poland, Romania, Russia, Serbia, the Slovak Republic, Slovenia, and Ukraine. The panel consists of two main components: tax variables and non-tax variables. Among tax variables, statutory CIT rate is the dependent variable, while the average regional unweighted (uniform) CIT rate, the average CIT rate weighted by GDP, and PIT rate are explanatory variables. Non-tax variables include the size of the country, government consumption, openness, and strength of institutions.

The average regional CIT rate is an average for all countries in the sample with (i) uniform weights and (ii) weighted by GDP, leaving out a particular country's statutory rate. PIT rates are defined as top marginal income tax rates. The size of the country is expressed by GDP in current US dollars, whereas government consumption is defined as the share of general government expenditures to GDP. Openness is proxied by a sum of imports and exports to GDP, while the rule of law is based on the World Bank's Governance Indicators index.

Table A1

\begin{tabular}{lcc}
\hline Variable & Acronym & Source \\
\hline Corporate Income Tax Rate (percent) & CIT & PriceWaterhouse Coopers \\
Average Corporate Income Tax Rate (percent) & CITUNI & Own calculations \\
$\begin{array}{l}\text { Average Corporate Income Tax Rate weighted by GDP } \\
\text { (percent) }\end{array}$ & CITGDP Own & calculations \\
Personal Income Tax Rate (percent) & PIT & PriceWaterhouse Coopers \\
Gross domestic product, current prices, U.S. dollars & GDPD & WEO \\
General gov. expenditure (\% of GDP) & GGE & WEO \\
Exports and Imports (\% of GDP) & OPEN & WEO \\
Rule of law (rank) & LAW & World Bank World \\
& & Governance Indicators \\
\hline
\end{tabular}

Table A2

\begin{tabular}{|c|c|c|c|c|}
\hline \multicolumn{5}{|c|}{ Data statistics } \\
\hline & Mean & $\begin{array}{l}\text { Std } \\
\text { dev }\end{array}$ & Min & Max \\
\hline $\mathrm{CIT}$ & 25.04 & 7.48 & 10.00 & 41.00 \\
\hline CITUNI & 24.50 & 3.22 & 18.53 & 28.75 \\
\hline CITGDP & 27.22 & 5.38 & 10.90 & 34.32 \\
\hline PIT & 33.11 & 10.66 & 10.00 & 60.00 \\
\hline GDPD & 54.86 & 113.12 & 1.17 & 984.92 \\
\hline GGE & 38.18 & 8.93 & 10.64 & 63.63 \\
\hline OPEN & 104.71 & 42.16 & 32.42 & 218.97 \\
\hline LAW & 11.33 & 3.77 & 2.00 & 19.00 \\
\hline
\end{tabular}




\section{Econometric methodology}

We use panel data regression to account for individual heterogeneity prevalent among countries in the sample. Panel regression provides more degrees of freedom and more efficiency to the estimates. Employing panel data techniques also gives more variability and less collinearity among explanatory variables (Baltagi, 2005).

An econometric representation of the panel data model takes the following form:

$y_{i t}=\alpha_{i}+\beta x_{i t}^{\prime}+u_{i t}$

where $x$ represents a vector of explanatory variables, $\alpha_{i}$ denotes the unobserved individual effects, $u_{i t}$ is the error term, and $i=1, \ldots, N ; t=1, \ldots, T$. The unobserved individual effects $\alpha_{i}$ are constant over time and represent heterogeneity not picked by the vector of explanatory variables $x$, while the error term $u_{i t}$ varies with individual and time.

We use the fixed effects (FE) method to account for the unobserved individual effects. This allows for making inferences about only a particular set of cross-section units i.e. countries, states or industries (Wooldridge, 2002). The one-way version of the FE procedure treats parameters $\alpha_{i}$ as fixed for each cross-section unit. The restriction allowing parameters $\alpha_{i}$ to vary across cross-section units can be tested via an F-test with the null hypothesis that the constant terms are equal across units. If the null hypothesis is rejected then the FE is preferred over the pooled OLS because the latter would produce inconsistent estimates. The two-way version of the FE procedure exploits the unobserved individual effects but additionally assumes common global or macroeconomic shocks. The prevalence of these common shocks can also be tested via an F-test.

We also test the OLS method. However, in OLS regressions some explanatory variables may be endogenous i.e. $\operatorname{Cov}(x, u) \neq 0$, in which case estimators are biased and inconsistent. To obtain consistent estimators of $\alpha$ and $\beta$ when $x$ and $u$ are correlated, we apply the method of an instrumental variable (IV). The method regresses those variables that are perceived as endogenous on instrumental variables $z$. The crucial condition for choosing instrumental variables is that they have to be correlated with the endogenous variables $\operatorname{Cov}(z, x) \neq 0$, but not with the error term of the underlying equation $\operatorname{Cov}(z, u)=0$. A special case of the generalized instrumental variable estimation when there are more instrumental variables than explanatory variables is two-stage least squares method (TSLS). However, the TSLS estimator can be less efficient than the OLS when the explanatory variables are actually exogenous. In such cases, standard errors for the TSLS tend to be substantially larger than for the OLS (Wooldridge, 2002). To test whether a variable is endogenous is crucial. Since the Hausman test (1978) can suffer from a finite sample bias and computational difficulties, we 
employ a test developed by Davidson and MacKinnon (1993). ${ }^{35}$ The null hypothesis states that variables are exogenous. Another test in the context of endogeneity is used to check the validity of instrumental variables. The test can be applied if and only if the system is overidentified, a situation in which the number of endogenous variables is less than the total number of variables excluded from the equation under consideration. The test of overidentifying restrictions developed by Sargan (1958) and modified by Hansen (1982) examine whether the instruments are valid in the sense they are not correlated with the error term in the underlying model. ${ }^{36}$

\section{Results}

The first step in the empirical analysis ignores potential endogeneity related to CIT and PIT rates. We use two specifications for both the average of uniform CIT rates and the weighted average of CIT rates. The first specification is basic and includes only tax variables as explanatory variables, while the second one includes also other control variables. For each specification, the pooled OLS and the FE estimators are employed. We apply the F-test to decide whether individual effects are present in the data. The prevalence of global shocks that may affect setting CIT rates is also tested via the F-test.

Table A3 presents the results for the regressions with the average of uniform CIT rates. The results are based on two specifications. The first specification includes only tax variables:

$\operatorname{cit}_{i t}=\alpha_{i}+\beta_{1}$ cituni $_{i t}+\beta_{2}$ pit $_{i t}+v_{i t}$

The second specification adds also other control variables:

$\operatorname{cit}_{i t}=\alpha_{i}+\beta_{1}$ cituni $_{i t}+\beta_{2}$ pit $_{i t}+\beta_{3} g d p d_{i t}+\beta_{4} g g e_{i t}+\beta_{5}$ open $_{i t}+\beta_{6}$ law $_{i t}+v_{i t}$

The basic specification including only tax variables provides evidence in favor of strategic interaction in setting CIT rates in the region. The coefficient associated with cituni has the right sign and is statistically significant for both the pooled OLS and the FE, although the Ftest suggests that unobserved individual effects are present in the data. Time dummies associated with global shocks turn out to be statistically insignificant, therefore are not included. The coefficient attached to pit is positive and statistically significant. The specification including also other control variables demonstrates the prevalence of the strategic interaction in the region too. Models for the pooled OLS and the FE are estimated, but the F-test suggests that country fixed effects are present in the data, whereas time

\footnotetext{
${ }^{35}$ Davidson and MacKinnon compare their test to the Hausman test. They show that the Hausman test can be computed if the difference of estimated covariance matrices is a positive definite, whereas their test always ensures a computable test statistic.

${ }^{36}$ The difference between the Sargan test and the Hansen test is that the former is consistent if the disturbance is homoskedastic but autocorrelated while the latter is consistent in the presence of heteroskedasticity and autocorrelation.
} 
dummies turn out to be statistically insignificant. The coefficient associated with pit is again positive and statistically significant. While the coefficient of gge is positive and statistically significant, the coefficient attached to open is negative but also statistically significant. Neither the size of the economy nor the rule of law is statistically significant.

Table A4 reports the results for the regressions with the weighted average of CIT rates. The results are again based on two specifications. The first specification includes only tax variables:

$\operatorname{cit}_{i t}=\alpha_{i}+\beta_{1} \operatorname{citgdp}_{i t}+\beta_{2}$ pit $_{i t}+v_{i t}$

The second specification extends the first one with other control variables:

$\operatorname{cit}_{i t}=\alpha_{i}+\beta_{1} \operatorname{citgdp}_{i t}+\beta_{2}$ pit $_{i t}+\beta_{3} g d_{p d}+\beta_{4} g g e_{i t}+\beta_{5}$ open $_{i t}+\beta_{6} \operatorname{law}_{i t}+v_{i t}$

Both the basic specification and the one with other control variables confirm that there is strategic interaction in setting CIT rates in the region. The coefficient associated with citgdp has the right sign and is statistically significant for the pooled OLS and the FE, but is lower than for cituni. The FE is preferred over the pooled OLS because the F-test indicates the prevalence of unobserved individual effects in the data, whereas time dummies turn out to be statistically insignificant. The variable pit has the right sign and turns out to be statistically significant. Other control variables such as gge, open, and gdpd have also the right sign and are statistically significant, although gdpd only marginally so. The rule of law is not again statistically significant.

The second step in the empirical analysis addresses the issue of potential endogeneity related to CIT rates and PIT rates. The reason why cituni and citgdp can be endogenous is that countries may respond to each other in setting CIT rates, as suggested by the theoretical model developed by Deveraux and others (2008). The reason why pit can be endogenous relative to CIT is that these two tax rates are often set simultaneously to avoid tax arbitrage. We test the endogeneity of variables with the Hausman test and the Davidson-MacKinnon test. It is followed by the Sargan test and the Hansen test of overidentifying restrictions to determine whether instrumental variables are valid.

Table A5 reports the results for the regressions with the average of uniform CIT rates. Both the basic specification and the one with other control variables show strategic interaction in setting CIT rates in the region. The hypothesis of strategic interaction postulated in the theoretical model is supported by the Hausman test and the Davidson-MacKinnon test, which indicate that cituni is indeed endogenous. The theory of strategic interaction is also backed by the coefficient attached to cituni, which has the right sign and is statistically significant for both the pooled OLS and the FE. Nonetheless, as a result of formal testing, the preference is given to the FE with no time dummies. The test of endogeneity for pit suggests that this variable is endogenous too. This reflects the fact that all the tax rates are determined simultaneously and the direction of changes in CIT and PIT rates is similar because some form of tax arbitrage would have existed otherwise. The impact of government consumption on CIT rates is positive and statistically significant, which reflects the fact that higher public 
spending requires at some stage higher tax revenues. The data also show that the more open economies are, the lower CIT rates can be set. This is because open economies are subject to tighter competition for capital than closed economies are. Therefore, to attract capital, open economies need to set their CIT rates at a lower level than feasible for closed economies. The size of the economy does not seem to affect statutory CIT rates, and neither does the rule of law.

Table A6 reports the results for the regressions with the weighted average of CIT rates. Both the basic specification and the one with other control variables suggest that strategic interaction in setting CIT rates is prevalent in the region. The theory is confirmed by the Hausman test and the Davidson-MacKinnon test that indicate cituni as an endogenous variable. The support for the theory also comes from the coefficient citgdp that has the expected positive sign and is statistically significant. The preferred specification is again the FE and time dummies are not included. The test for endogeneity of pit suggests that this variable is endogenous too. This is because all the tax rates are determined within the same time frame and that there is some form of co-ordination in setting CIT and PIT rates at the national level to avoid tax arbitrage. Statutory CIT rates are positively affected by government consumption, which reflects the fact that higher public spending requires at some stage higher tax revenues. The impact of openness turns out to be negative and statistically significant. Neither the size of the economy nor the rule of law is statistically significant. 
Table A3

\begin{tabular}{lcccc}
\hline & ols & fe & ols & fe \\
\hline cituni & 0.9070 & 0.9170 & 0.9090 & 0.6170 \\
& $(0.1100)^{\star \star \star}$ & $(0.0969)^{\star \star \star}$ & $(0.2120)^{\star \star \star}$ & $(0.1720)^{\star \star \star}$ \\
pit & 0.1870 & 0.1840 & 0.1980 & 0.1410 \\
& $(0.0381)^{\star \star \star}$ & $(0.0587)^{\star \star \star}$ & $(0.0442)^{\star \star \star}$ & $(0.0539)^{\star \star \star}$ \\
gdpd & & & 0.0123 & -0.0071 \\
& & $(0.0032)^{\star \star \star}$ & $(0.0054)$ \\
gge & & 0.0075 & 0.2640 \\
& & $(0.0621)$ & $(0.0783)^{\star \star \star}$ \\
open & & -0.0024 & -0.0639 \\
& & $(0.0103)$ & $(0.0191)^{\star \star \star}$ \\
law & & -0.0651 & 0.0673 \\
& & & $(0.1850)$ & $(0.1700)$ \\
R2 adj & 0.5110 & 0.3960 & 0.5490 \\
indiv dummies & $F(19,198)=33.77$ & $F(19,194)=33.84$ \\
p-level & 0.0000 & \multicolumn{2}{c}{0.0000} \\
time dummies & $F(11,207)=0.39$ & $F(11,203)=$ & 0.50 \\
p-level & \multicolumn{2}{c}{0.9600} & 0.9016 \\
\hline
\end{tabular}

Robust standard errors. ${ }^{\star *}$ significant at $1 \%,{ }^{* \star}$ significant at $5 \%$,

* significant at $10 \%$

Table A4

\begin{tabular}{lcccc}
\hline & ols & fe & ols & fe \\
\hline citgdp & 0.2730 & 0.6230 & 0.3220 & 0.4440 \\
& $(0.0781)^{\star \star \star}$ & $(0.0659)^{\star \star \star}$ & $(0.1600)^{\star \star}$ & $(0.1310)^{\star \star \star}$ \\
pit & 0.2380 & 0.1820 & 0.2170 & 0.1400 \\
& $(0.0395)^{\star \star \star}$ & $(0.0585)^{\star \star \star}$ & $(0.0454)^{\star \star \star}$ & $(0.0551)^{\star \star \star}$ \\
gdpd & & & 0.0181 & -0.0096 \\
& & $(0.0051)^{\star \star \star}$ & $(0.0058)^{\star}$ \\
gge & & 0.0374 & 0.2720 \\
& & $(0.0650)$ & $(0.0765)^{\star \star \star}$ \\
open & & -0.0139 & -0.0630 \\
& & $(0.0108)$ & $(0.0200)^{\star \star \star}$ \\
law & & -0.3280 & 0.1210 \\
& & $(0.2050)$ & $(0.1810)$ \\
R2 adj & 0.2440 & 0.3490 & 0.5430 \\
indiv dummies & $F(19,198)=50.61$ & $F(19,194)=$ & 40.34 \\
p-level & 0.0000 & 0.0000 \\
time dummies & $F(11,207)=0.87$ & $F(11,203)=$ & 1.18 \\
p-level & \multicolumn{2}{c}{0.5749} & 0.3050 \\
\hline
\end{tabular}

Robust standard errors. ${ }^{\star \star \star}$ significant at $1 \%$, ${ }^{\star \star}$ significant at $5 \%$,

* significant at $10 \%$ 
Table A5

\begin{tabular}{|c|c|c|c|c|}
\hline & pols-iv & fe-iv & pols-iv & fe-iv \\
\hline cituni & $\begin{array}{c}0.9140 \\
(0.1250)^{\star \star \star}\end{array}$ & $\begin{array}{c}0.8450 \\
(0.1210)^{\star \star \star}\end{array}$ & $\begin{array}{c}0.7290 \\
(0.2220)^{\star \star \star}\end{array}$ & $\begin{array}{c}0.5090 \\
(0.2600)^{\star \star}\end{array}$ \\
\hline pit & $\begin{array}{c}0.1840 \\
(0.0420)^{\star \star \star}\end{array}$ & $\begin{array}{c}0.2970 \\
(0.0764)^{\star \star \star}\end{array}$ & $\begin{array}{c}0.2160 \\
(0.0521)^{\star \star \star}\end{array}$ & $\begin{array}{c}0.2700 \\
0.0699)^{\star \star \star}\end{array}$ \\
\hline gdpd & & & $\begin{array}{c}0.0121 \\
(0.0037)^{\star \star \star}\end{array}$ & $\begin{array}{l}-0.0023 \\
(0.0043)\end{array}$ \\
\hline gge & & & $\begin{array}{l}-0.0049 \\
(0.0613)\end{array}$ & $\begin{array}{c}0.2610 \\
0.0959)^{\star \star \star}\end{array}$ \\
\hline open & & & $\begin{array}{l}-0.0051 \\
(0.0108)\end{array}$ & $\begin{array}{c}-0.0441 \\
(0.0213)^{\star \star}\end{array}$ \\
\hline law & & & $\begin{array}{l}-0.3220 \\
(0.2260)\end{array}$ & $\begin{array}{l}-0.1460 \\
(0.2960)\end{array}$ \\
\hline R2 adj & 0.3590 & 0.4860 & 0.3880 & 0.5190 \\
\hline $\begin{array}{l}\text { indiv dummies } \\
\text { p-level }\end{array}$ & $\begin{array}{r}F(19,198)= \\
0.0000\end{array}$ & $=33.77$ & $\begin{array}{r}F(19,194)= \\
0.0000\end{array}$ & 0 \\
\hline $\begin{array}{l}\text { time dummies } \\
\text { p-level }\end{array}$ & $\begin{array}{r}F(11,207)= \\
0.9600\end{array}$ & $\begin{array}{l}=0.39 \\
00\end{array}$ & $\begin{array}{r}F(11,203)= \\
0.9016\end{array}$ & $=6^{0.50}$ \\
\hline $\begin{array}{l}\text { Durbin-Wu-Hausman chi-sq } \\
\text { test } \\
\text { P-value }\end{array}$ & 7.77938 & & 9.71926 & \\
\hline Davidson-MacKinnon test & & 3.99566 & & 3.563881 \\
\hline P-value & & 0.0203 & & 0.0307 \\
\hline Sargan $N^{*} R$-sq test & 1.645 & & 2.272 & \\
\hline P-value & 0.4394 & & 0.3211 & \\
\hline Hansen test & & 1.824 & & 0.633 \\
\hline P-value & & 0.4016 & & 0.7289 \\
\hline
\end{tabular}

Robust standard errors. ${ }^{* \star}$ significant at $1 \%,{ }^{* \star}$ significant at $5 \%,{ }^{*}$ significant at $10 \%$ 
Table A6

\begin{tabular}{|c|c|c|c|c|}
\hline & pols-iv & fe-iv & pols-iv & fe-iv \\
\hline citgdp & $\begin{array}{c}0.3110 \\
(0.0875)^{\star \star \star}\end{array}$ & $\begin{array}{c}0.6230 \\
(0.0915)^{\star \star \star}\end{array}$ & $\begin{array}{c}0.2390 \\
(0.1820)\end{array}$ & $\begin{array}{c}0.4450 \\
(0.2100)^{\star \star}\end{array}$ \\
\hline pit & $\begin{array}{c}0.2330 \\
(0.0465)^{\star \star \star}\end{array}$ & $\begin{array}{c}0.3130 \\
(0.0769)^{\star \star \star}\end{array}$ & $\begin{array}{c}0.2440 \\
(0.0533)^{\star \star \star}\end{array}$ & $\begin{array}{c}0.2830 \\
(0.0740)^{\star \star \star}\end{array}$ \\
\hline gdpd & & & $\begin{array}{c}0.0167 \\
(0.0044)^{\star \star \star}\end{array}$ & $\begin{array}{l}-0.0032 \\
(0.0046)\end{array}$ \\
\hline gge & & & $\begin{array}{c}0.0161 \\
(0.0630)^{*}\end{array}$ & $\begin{array}{c}0.2610 \\
(0.0904)^{\star \star}\end{array}$ \\
\hline open & & & $\begin{array}{l}-0.0149 \\
(0.0106)\end{array}$ & $\begin{array}{c}-0.0406 \\
(0.0222)^{\star \star}\end{array}$ \\
\hline law & & & $\begin{array}{c}-0.6360 \\
(0.2530)^{\star \star \star}\end{array}$ & $\begin{array}{l}-0.0345 \\
(0.3090)\end{array}$ \\
\hline $\mathrm{R}$ adj & 0.2050 & 0.4750 & 0.3470 & 0.5120 \\
\hline $\begin{array}{l}\text { indiv dummies } \\
\text { p-level }\end{array}$ & \multicolumn{2}{|c|}{$\begin{array}{l}198)=50 \\
0.0000\end{array}$} & \multicolumn{2}{|c|}{$\begin{array}{c}F(19,194)=40.34 \\
0.0000\end{array}$} \\
\hline $\begin{array}{l}\text { time dummies } \\
\text { p-level }\end{array}$ & \multicolumn{2}{|c|}{$\begin{array}{c}F(11,207)=0.87 \\
0.5749\end{array}$} & \multicolumn{2}{|c|}{$\begin{array}{c}F(11,203)=1.18 \\
0.3050\end{array}$} \\
\hline $\begin{array}{l}\text { Durbin-Wu-Hausman chi-sq } \\
\text { test }\end{array}$ & 8.36792 & & 10.34502 & \\
\hline $\mathrm{p}$-value & 0.01524 & & 0.00567 & \\
\hline $\begin{array}{l}\text { Davidson-MacKinnon test } \\
\text { p-value }\end{array}$ & & $\begin{array}{c}5.280987 \\
0.006\end{array}$ & & $\begin{array}{c}3.977604 \\
0.0207\end{array}$ \\
\hline $\begin{array}{l}\text { Sargan } N^{*} R \text {-sq test } \\
p \text {-value }\end{array}$ & $\begin{array}{c}3.192 \\
0.2027\end{array}$ & & $\begin{array}{c}2.619 \\
0.27\end{array}$ & \\
\hline Hansen test & & 1.382 & & 0.767 \\
\hline$p$-value & & 0.5012 & & 0.6813 \\
\hline
\end{tabular}

